\title{
Effect of Mikania glomerata (Asteraceae) leaf extract combined with anti-venom serum on experimental Crotalus durissus (Squamata: Viperidae) envenomation in rats
}

\author{
Rafael Stuani Floriano ${ }^{1}$, Rosa Maria Barilli Nogueira ${ }^{2}$, Michiko Sakate ${ }^{3}$, Cecília Braga Laposy ${ }^{4}$, \\ Yudney Pereira da Motta $^{3}$, Fabíola Sangiorgio ${ }^{3}$, Heloísa Costa David ${ }^{2}$ \& João Marcelo Nabas ${ }^{5}$ \\ 1. Masters degree postgraduate in Animal Science at University of Western São Paulo - UNOESTE, Presidente Prudente, \\ SP, Brazil; rafael_stuani@hotmail.com \\ 2. Department of Small Animals, Medical Clinic, University of Western São Paulo, UNOESTE, Presidente Prudente, SP, \\ Brazil; rosa@unoeste.br \\ 3. Department of Veterinary Clinic, School of Veterinary Medicine and Animal Husbandry, São Paulo State University, \\ UNESP, Botucatu, SP, Brazil \\ 4. Department of Clinical Pathology, UNOESTE, Presidente Prudente, SP, Brazil; \\ 5. Department of Pharmacology, Adamantinenses Integrated Schools, FAI, Adamantina, SP, Brazil
}

Received 20-XI-2009. Corrected 20-IV-2009. Accepted 19-V-2009.

\begin{abstract}
Crotalic envenomation represents the highest number of deaths when compared to other snakebite envenomations of medical interest. Crotalic venom has important characteristics such as neurotoxicity, myotoxicity, nephrotoxicity, and clotting and hemolytic action. We evaluated the clinical and laboratory aspects of Crotalus durissus terrificus experimental envenomation in Wistar rats treated with antivenom and the aqueous extract of the plant Mikania glomerata. The animals were divided into three groups: Group C (control); Group $V S$-venom and antivenom; Group VSM-venom, antivenom and aqueous extract of M. glomerata. Crotalic poison caused clinical and laboratory alterations in Wistar mice. Significant clinical alterations were: temperature decrease, edema in the venom inoculated member, sedation and a locomotion decrease in groups VS and VSM when compared with group C. A faster recovery from sedation was observed only for animals of group VSM when compared to VS. There was an increase in the number of leukocytes, neutrophils and creatine kinase in the VS and VSM groups, compared to group C. Wistar rats showed a high resistance to crotalic venom. Additional studies with different doses, time of treatment, different administration methods and histopathological and immunological studies are necessary to understand the action of M. glomerata in crotalic accidents. Rev. Biol. Trop. 57 (4): 929-937. Epub 2009 December 01.
\end{abstract}

Keywords: Crotalus durissus terrificus, Mikania glomerata, antivenom, rat, venom.

Crotalus durissus terrificus snakebites are the second most common cause of casualties in Brazil, and the number one cause of death (Ministério da Saúde 2005, Ministério da Saúde 2006). Crotalic venom has neurotoxic (Vital-Brazil 1972, Amaral et al. 1991, Jorge \& Ribeiro 1992), systemic myotoxic, and nefrotoxic actions (Amaral et al. 1986, Azevedo-Marques et al. 1985, Castro 2006). It also changes blood clotting (Amaral et al. 1988 ) and causes hemolysis in vitro (Rosenfeld et al. 1962, Kelen et al. 1962).
Factors like animal species, age, weight, general conditions of the individual organism, amount of injected venom, bite site and time from the envenomation until treatment, contribute to the level of gravity of the envenomation (Murtaugh \& Kaplan 1992, Pinho \& Pereira 2001).

Serum therapy is the regular treatment, but it is of great importance to find supplementary treatments that might reduce the intensity and gravity of clinical changes, reducing not only the incidence of secondary complications, but 
also the number of deaths (Ferreira et al. 1992, Pereira et al. 1994, Melo et al. 1994, Ministério da Saúde 2001, Maiorano et al. 2005).

Some plants with antivenom properties are mentioned in the literature (Soares et al. 2004, Soares et al. 2005), and the Mikania glomerata species (F. Asteracea), popularly known as "guaco", was used in this study. Its extract major component is Cumarine (1,2-benzopiren) that contributes to its antivenom activity (Leite et al. 1993). The literature mentions that such plants inhibit the action of several snake venoms. Besides, it is a rich source of potential inhibitors of PLA2, metalloproteases and serine proteases, which are enzymes related to the clinical signs observed in humans and animals (Maiorano et al. 2005). This study evaluated the clinical and laboratory aspects of Crotalus durissus terrificus experimental envenomation in Wistar rats treated with antivenom and the aqueous extract of Mikania glomerata.

\section{MATERIAL AND METHODS}

The experimental protocol was approved by the Ethics Committee of University of Western São Paulo, UNOESTE, Presidente Prudente, Brazil (036/06).

Experimental groups: Fifty-four females of the Rattus norvegicus species (Berkenhout 1769) of the Wistar rat line, weighting between 200 and $300 \mathrm{~g}$, were divided into three experimental groups of 18 animals per group. The groups were divided as follows: group VS (venom+serum) received $10 \mathrm{mg} / \mathrm{kg}$ of crotalic venom via intramuscular injection in the rear left limb and antivenom (Vencofarma ${ }^{\circledR}$ ) intraperitoneally at the manufacturer's recommended dose in order to neutralize the amount of inoculated venom; group VSM (venom + serum $+M$. glomerata) received the same dose of venom and antivenom as Group VS, and an aqueous leaf extract from the plant at a $10 \%$ concentration (orally) every hour starting after venom inoculation until a total of five doses was reached. Animals were evaluated at three different times: M1-30 minutes after venom inoculation; M2-6 hours after venom inoculation; M3-24 hours after venom inoculation.

Animals were housed in stainless steel cages and maintained under standard conditions (12h light/12h dark cycle, constant temperature of $22^{\circ} \mathrm{C}$ and humidity of $55 \%$ ). Filtered water and rations were offered ad libitum.

Venom: Venom was provided by the Center for the Study of Venoms and Venomous Animals, CEVAP-UNESP, Botucatu, São Paulo, Brazil. Lyophilized venom was diluted in sterile saline solution at a $5 \mathrm{mg} / \mathrm{mL}$ concentration and inoculated via intramuscular injection in the animal's rear left limb (lateral face of the thigh).

Antiophidic serum: The bothropic-crotalic serum used was from Vencofarma Laboratory serum (Vencofarma ${ }^{\circledR}$ ); each flask of $10 \mathrm{~mL}$ of serum neutralizes $10 \mathrm{mg}$ of crotalic venom. It was administered intraperitoneally six hours after venom inoculation.

Aqueous leaf extract of $M$. glomerata: The extract was prepared at the Pharmacology Laboratory of Adamantinenses Integrated School, FAI, Adamantina, SP, Brazil. The leaves of "guaco" (M. glomerata) were collected from plants that were grown in an area that was constantly supervised and checked. The extract preparation followed the Brazilian Pharmacopeia protocol (Silva 1929). The aqueous solution was used at $10 \%$ concentration and was intragastrically administered (gavage) in $10 \mathrm{mg} / \mathrm{kg}$ doses, determined in pilot experiments, starting soon after the crotalic venom inoculation and repeated every hour until 5 doses had been given. The plant was identified by Professor Nelson Barbosa Machado Neto of the Universidade do Oeste PaulistaUNOESTE and a voucher specimen (16838) of the plant has been deposited at the Department of Botânica-IBB-UNESP Botucatu, SP.

Physical exam: The physical exan consisted of the evaluation of heart frequency for the inspection of beats per minute (bpm), 
breathing frequency for the inspection of the movements per minute (mpm), and temperature was determined with a rectal digital thermometer. The progress of edema was evaluated with a pachymeter after the injection of crotalic venom. Observation of the locomotion was classified into either 1-present or 2-absent. Observation of the sedation degree was classified as either 1-light (gets up when stimulated), 2-moderate (answers to incentives but stays in decubitus), or 3-intense (does not answer to incentives). The time of coagulation was determined using the capillary method (Jain 1993) after collection of blood from the tail. Coagulation was classified as either 1-coagulated or 2-not coagulated.

Hematology: Animals were subjected to euthanasia by the end of each period using $150 \mathrm{mg} / \mathrm{kg}$ of intaperitoneal pentobarbital. Euthanasia was conducted soon after the intracardiac collection of blood. Total counting of erythrocyte and hemoglobin dosage for the cyanometahemoglobin method was performed by electronically counting the cells (CELMCC530). Globular volume for the microhematocrit method was performed using a personal computer EULAB, model 024. The total plasma protein for refratometry (AST-Japan), fibrinogen for the precipitation technique for heat analysis (Kaneko et al. 1997), counting of leukocytes and differential counting of leukocytes was accomplished in 100 cells in a smear stained with fast Panotico (LABOR-CLIN) (Jain 1993).

Serum chemistry: Urea (Kit LabestLagoa Santa-MG), creatinine (Kit BioclinBelo Horizonte-MG), creatine kinase (CK)(Kit Doles-Goiânia-GO) (Kaneko et al 1997).

Statistical analysis: Parametric data were subjected to variance analysis. Non-parametric data were subjected to Kruskal-Wallis analysis (Curi 1997).

\section{RESULTS}

Clinical exam: After venom inoculation, all animals presented discomfort, uneasiness, ataxia, pain and retraction of the limb where inoculation took place. Animals from groups VS and VSM presented edema of both rear limbs, with the left one being more swollen. Animals from group VS presented statistically significant edema $(\mathrm{p}<0.05)$ at M1, M2 and M3 when compared to the control group, and in group VSM, edema was more noticeable at M1. Intense edema was noticed in animals from group VS when compared to VSM (Table 1).

A significant drop in temperature $(\mathrm{p}<0.05)$ was noticed after six hours of inoculation for animals of groups VS and VSM, when compared to the control, and the values returned closer to the control group after 24 hours. In spite of not being statistically significant, a larger decrease in heart frequency was observed at two periods (M2 and M3) for group VS compared with the decrease at one period (M3) for group VSM (Table 1).

Moderate sedation at period M2 was statistically significant $(p<0.05)$ for groups VS and VSM compared to group C. The animals of group VSM totally recovered at period M3, faster than the animals of group VS for the same period of time (Table 1).

The locomotion diminution was significant $(p<0.05)$ at M2 for groups VS and VSM when compared to group $\mathrm{C}$, and by clinical observation, animals from group VSM recovered faster then those of group VS (Table 1).

Laboratory analysis: Blood incoaguability was only observed in two animals; one from group VS at M1, and another from group VSM at M3. Thus, this information was neither statistically or clinically significant.

The number of red blood cells, hemoglobin and globular volume diminished at all periods for all animals from groups VS and VSM compared to the control group. Nevertheless, 
TABLE 1

Average and standard deviation of the values found in the clinical exam in the different groups at different periods

\begin{tabular}{|c|c|c|c|c|}
\hline \multirow[b]{2}{*}{ Variable } & \multirow[b]{2}{*}{ Groups } & \multicolumn{3}{|c|}{ Periods } \\
\hline & & $\begin{array}{l}\text { M1 = } 30 \text { minutes } \\
\text { after inoculation }\end{array}$ & $\begin{array}{l}\mathrm{M} 2=6 \text { hours } \\
\text { after inoculation }\end{array}$ & $\begin{array}{l}\text { M3 = } 24 \text { hours } \\
\text { after inoculation }\end{array}$ \\
\hline Edema (member inoculated with venom) & $\begin{array}{c}\text { C } \\
\text { VS } \\
\text { VSM }\end{array}$ & $\begin{array}{c}0.77 \pm 0.10 \\
1.32 \pm 0.12^{\mathrm{A}} \\
1.33 \pm 0.16^{\mathrm{A}}\end{array}$ & $\begin{array}{c}0.88 \pm 0.16 \\
1.53 \pm 0.20^{\mathrm{A}} \\
1.08 \pm 0.13^{\mathrm{A}}\end{array}$ & $\begin{array}{c}0.77 \pm 0.08 \\
1.15 \pm 0.29^{\mathrm{A}} \\
1.28 \pm 0.10^{\mathrm{A}}\end{array}$ \\
\hline Temperature & $\begin{array}{c}\text { C } \\
\text { VS } \\
\text { VSM }\end{array}$ & $\begin{array}{l}37.1 \pm 0.2 \\
37.3 \pm 0.7 \\
36.1 \pm 1.7\end{array}$ & $\begin{array}{c}37.2 \pm 0.3 \\
34.6 \pm 1.6^{\mathrm{A}} \\
35.2 \pm 1.1^{\mathrm{A}}\end{array}$ & $\begin{array}{l}36.6 \pm 0.8 \\
35.8 \pm 0.9 \\
35.8 \pm 0.9\end{array}$ \\
\hline Respiratory frequency & $\begin{array}{c}\text { C } \\
\text { VS } \\
\text { VSM }\end{array}$ & $\begin{array}{c}104.3 \pm 17.4 \\
112.7 \pm 25 \\
96 \pm 17.2\end{array}$ & $\begin{array}{c}101.7 \pm 17.6 \\
90.3 \pm 16.4 \\
119.7 \pm 25.1\end{array}$ & $\begin{array}{c}116.3 \pm 24.6 \\
121.0 \pm 8.9 \\
119.2 \pm 18.1\end{array}$ \\
\hline Heart frequency & $\begin{array}{c}\text { C } \\
\text { VS } \\
\text { VSM }\end{array}$ & $\begin{array}{l}218 \pm 11.2 \\
212 \pm 18.7 \\
213 \pm 17.8\end{array}$ & $\begin{array}{l}218 \pm 13.1 \\
202 \pm 43.1 \\
210 \pm 15.1\end{array}$ & $\begin{array}{l}210 \pm 14.3 \\
126 \pm 77.2 \\
179 \pm 30.8\end{array}$ \\
\hline Sedation & $\begin{array}{c}\mathrm{C} \\
\mathrm{VS} \\
\mathrm{VSM}\end{array}$ & $\begin{array}{l}1.0(1.0 ; 1.0) \\
1.0(1.0 ; 1.0) \\
1.0(1.0 ; 1.0)\end{array}$ & $\begin{array}{c}1.0(1.0 ; 1.0) \\
2.0(1.0 ; 2.0)^{\mathrm{AB}} \\
2.0(2.0 ; 2.0)^{\mathrm{AB}}\end{array}$ & $\begin{array}{c}1.0(1.0 ; 1.0) \\
1.5(1.0 ; 2.0)^{\mathrm{A}} \\
1.0(1.0 ; 1.0)\end{array}$ \\
\hline Locomotion & $\begin{array}{c}\text { C } \\
\text { VS } \\
\text { VSM }\end{array}$ & $\begin{array}{l}1.0(1.0 ; 1.0) \\
1.0(1.0 ; 1.0) \\
1.0(1.0 ; 1.0)\end{array}$ & $\begin{array}{c}1.0(1.0 ; 1.0) \\
2.0(1.0 ; 2.0)^{\mathrm{AB}} \\
2.0(1.0 ; 2.0)^{\mathrm{AB}}\end{array}$ & $\begin{array}{l}1.0(1.0 ; 1.0) \\
1.0(1.0 ; 2.0) \\
1.0(1.0 ; 1.0)\end{array}$ \\
\hline
\end{tabular}

$\mathrm{A}=\mathrm{p}<0.05$ compare groups. $\mathrm{B}=\mathrm{p}<0.05$ compare periods.

C-control; VS-venom and antivenom; VSM-venom, antivenom and aqueous extract of M. glomerata.

Units are as follows: Rear left limb edema: $\mathrm{cm}$. Temperature: degrees celsius. Respiratory frequency: movements per minute (mpm). Heart frequency: beats per minute (bpm).

Normal values: Temperature $=35.9-37.5^{\circ} \mathrm{C}$; Respiratory frequency $=70-120 \mathrm{mpm}$; Heart frequency $=210-450 \mathrm{bpm}$.

this was much more evident in group VS than in group VSM (Table 2).

An increase in the number of leukocytes and neutrophils $(\mathrm{p}<0.05)$ was observed in groups VS and VSM at M1 and M2 when compared to group C. Within the same group, when comparing among the observed time periods, neutrophil increase was larger $(\mathrm{p}<0.05)$ at period M2 than M1; while, lymphocytes were reduced for groups VS and VSM at M2, and for group VSM at M3 (Table 2).

Total plasma protein, fibrinogen, urea and creatinine values were within regular values for the species. Creatinine kinase levels were significantly higher $(\mathrm{p}<0.05)$ for groups VS and VSM at M1 and M2 compared with the control group. Values returned to normal for both groups at M3, but resulted higher for the animals of VS group (Table 3).

\section{DISCUSSION}

Edema happens due to direct poison action in muscles, and it has systemic effects on crotoxin, phospholipase A2, and several other substances that are released in the acute inflammatory phase such as interleukin, bradikinine and histamine (Kini \& Evans 1989, Barraviera 1994). The results that were observed in this study agree with other authors that mention discreet to moderate edema at the site of inoculation of the venom (Hudelson \& Hudelson 1995, Collicchio et al. 2002, Nogueira et al. 2007).

Animals of group VSM presented less intense edema in the member where the venom was inoculated, due to the action of the $M$. glomerata, agreeing with the results of Maiorano et al. (2005), that the plant can inhibit the activity of phospholipase A2 in mice. In 
TABLE 2

Average and standard deviation of the values found in the hematology in the different groups at different periods

\begin{tabular}{|c|c|c|c|c|}
\hline \multirow[b]{2}{*}{ Variable } & \multirow[b]{2}{*}{ Groups } & \multicolumn{3}{|c|}{ Periods } \\
\hline & & $\begin{array}{l}\text { M1 = } 30 \text { minutes } \\
\text { after inoculation }\end{array}$ & $\begin{array}{c}\text { M2 = } 6 \text { hours } \\
\text { after inoculation }\end{array}$ & $\begin{array}{l}\text { M3 = } 24 \text { hours } \\
\text { after inoculation }\end{array}$ \\
\hline Red blood cells & $\begin{array}{c}\mathrm{C} \\
\mathrm{VS} \\
\mathrm{VSM}\end{array}$ & $\begin{array}{c}8.11 \pm 469.65 \\
8.64 \pm 623.56 \\
10.37 \pm 1.007 .08\end{array}$ & $\begin{array}{l}6.93 \pm 389.05 \\
6.27 \pm 778.08 \\
8.17 \pm 635.94\end{array}$ & $\begin{array}{l}6.89 \pm 261.30 \\
7.28 \pm 838.97 \\
8.74 \pm 482.86\end{array}$ \\
\hline Hemoglobin & $\begin{array}{c}\mathrm{C} \\
\mathrm{VS} \\
\mathrm{VSM}\end{array}$ & $\begin{array}{l}14.58 \pm 0.2 \\
17.57 \pm 0.4 \\
19.56 \pm 1.0\end{array}$ & $\begin{array}{c}13.95 \pm 0.6 \\
16.33 \pm 1.38 \\
16.35 \pm 0.1\end{array}$ & $\begin{array}{c}14.25 \pm 0.42 \\
14.95 \pm 0.83 \\
15.77 \pm 0.8\end{array}$ \\
\hline Globular Volume & $\begin{array}{c}\mathrm{C} \\
\mathrm{VS} \\
\mathrm{VSM}\end{array}$ & $\begin{array}{l}43.50 \pm 1.04 \\
53.67 \pm 1.96 \\
55.23 \pm 3.87\end{array}$ & $\begin{array}{l}42.17 \pm 1.32 \\
49.00 \pm 3.68 \\
49.17 \pm 1.32\end{array}$ & $\begin{array}{c}42.50 \pm 0.54 \\
45.00 \pm 2.68 \\
47.83 \pm 2.4\end{array}$ \\
\hline Leukocytes & $\begin{array}{c}\mathrm{C} \\
\mathrm{VS} \\
\mathrm{VSM}\end{array}$ & $\begin{array}{c}5.33 \pm 1,087.5 \\
10.08 \pm 3,185.9^{\mathrm{AB}} \\
9.88 \pm 2,472.6^{\mathrm{AB}}\end{array}$ & $\begin{array}{c}5.18 \pm 670.57 \\
8.33 \pm 2,739.8^{\mathrm{AB}} \\
14.01 \pm 5,093.7^{\mathrm{AB}}\end{array}$ & $\begin{array}{c}5.36 \pm 939.5 \\
3.58 \pm 1,049.6 \\
5.30 \pm 2,383.3\end{array}$ \\
\hline Neutrophils & $\begin{array}{c}\mathrm{C} \\
\mathrm{VS} \\
\mathrm{VSM}\end{array}$ & $\begin{array}{c}2.29 \pm 548.48 \\
4.87 \pm 1,180.7^{\mathrm{AB}} \\
3.86 \pm 1,060.2^{\mathrm{A}}\end{array}$ & $\begin{array}{c}1.78 \pm 380.08 \\
6.74 \pm 2.195 .4^{\mathrm{AB}} \\
11.07 \pm 4,591.3^{\mathrm{AB}}\end{array}$ & $\begin{array}{c}2.01 \pm 205.83 \\
1.66 \pm 517.87 \\
4.03 \pm 1,825.7\end{array}$ \\
\hline Lymphocytes & $\begin{array}{c}\mathrm{C} \\
\mathrm{VS} \\
\mathrm{VSM}\end{array}$ & $\begin{array}{l}2.56 \pm 490.95 \\
4.27 \pm 2,179.6 \\
5.16 \pm 1,726.5\end{array}$ & $\begin{array}{l}3.07 \pm 574.40 \\
1.16 \pm 548.71 \\
2.37 \pm 696.82\end{array}$ & $\begin{array}{l}2.73 \pm 871.64 \\
1.57 \pm 480.66 \\
2.83 \pm 710.10\end{array}$ \\
\hline Total plasma protein & $\begin{array}{c}\mathrm{C} \\
\mathrm{VS} \\
\mathrm{VSM}\end{array}$ & $\begin{array}{c}6.40 \pm 0.12 \\
6.30 \pm 0.41 \\
6.267 \pm 0.37\end{array}$ & $\begin{array}{l}6.10 \pm 0.27 \\
5.83 \pm 0.34 \\
6.33 \pm 0.30\end{array}$ & $\begin{array}{l}6.90 \pm 0.20 \\
7.53 \pm 0.35 \\
6.53 \pm 0.56\end{array}$ \\
\hline Fibrinogen & $\begin{array}{c}\mathrm{C} \\
\mathrm{VS} \\
\mathrm{VSM}\end{array}$ & $\begin{array}{c}300.00 \pm 109.54 \\
200.00 \pm 0 \\
233.33 \pm 81.65\end{array}$ & $\begin{array}{c}233.33 \pm 81.650 \\
300.00 \pm 109.54 \\
266.67 \pm 103.28\end{array}$ & $\begin{array}{c}266.67 \pm 103.28 \\
366.67 \pm 150.55 \\
366.67 \pm 81.33\end{array}$ \\
\hline
\end{tabular}

$\mathrm{A}=\mathrm{p}<0.05$ compare groups. $\mathrm{B}=\mathrm{p}<0.05$ compare periods.

C-control; VS-venom and antivenom; VSM-venom, antivenom and aqueous extract of M.glomerata.

Units are as follows. Red blood cells: $\times 10^{6} / \mathrm{mm}^{3}$. Hemoglobin and total plasma protein: g/dL. Globular volume: \%. Leukocytes, neutrophils and lymphocytes: $x 10^{3} / \mathrm{mm}^{3}$. Fibrinogen: $\mathrm{mg} / \mathrm{dL}$.

the present study, only the leaves were used for preparation of the plant extract, and in the study accomplished by Maiorano et al. (2005), the leaves, stalks and roots were used, which inhibited $100 \%$ the phospholipase A2 activity.

Temperature decrease occurred due to the state of shock and release of vasoactive agents at anaphylaxis, which is consistent with other reports, including hypothermia between six and 24 hours after venom inoculation (Lago et al. 2000, Raiser 2002, Nogueira \& Sakate 2006).

Dyspnea and lower respiratory and cardiac frequencies were seen, especially in animals from group VS, which are related to the crotalic venom's myotoxic and neurotoxic action. This goes along with findings from Amaral et al. (1991), Nogueira \& Sakate (2006) and Nogueira et al. (2007).

Sedation, diminution of locomotion and ataxia occurs due to the action of the crotoxin and crotamine on the central and outlying nervous system (Araújo\& Belluomini 1962, Azevedo-Marques et al. 1985, Barraviera 1994, Vieira et al. 2006). The results from this study are in accordance with the findings from other authors that report the same clinical signs 
TABLE 3

Average and standard deviation of the values found in the serum biochemistry in the different groups at different periods

$\begin{array}{lcccc}\text { Variable } & \text { Groups } & \begin{array}{c}\text { M1 }=30 \text { minutes } \\ \text { after inoculation }\end{array} & \begin{array}{c}\text { Periods } \\ \text { after inoculation }\end{array} & \begin{array}{c}\text { M3 }=24 \text { hours } \\ \text { after inoculation }\end{array} \\ \text { Urea } & \text { C } & 39.90 \pm 15.6 & 44.90 \pm 11.7 & 47.68 \pm 1.85 \\ & \text { VS } & 47.68 \pm 1.85 & 60.70 \pm 9.29 & 41.17 \pm 5.27 \\ \text { Creatinine } & \text { VSM } & 67.75 \pm 5.7 & 62.60 \pm 9.8 & 83.02 \pm 47.59 \\ & \text { C } & 0.59 \pm 0.52 & 0.57 \pm 0.57 & 0.46 \pm 0.46 \\ \text { Creatinine kinase } & \text { VS } & 0.94 \pm 0.07 & 0.59 \pm 0.02 & 0.62 \pm 0.14 \\ & \text { VSM } & 0.75 \pm 0.1 & 0.55 \pm 0.07 & 0.66 \pm 0.06 \\ & \text { VS } & 38.92 \pm 24 & 60.50 \pm 36.65 & 68.05 \pm 33.42 \\ & \text { VSM } & 477.42 \pm 195.59^{\mathrm{AB}} & 385.08 \pm 206.17^{\mathrm{AB}} & 68.05 \pm 33.42\end{array}$

$\mathrm{A}=\mathrm{p}<0.05$ compare groups. $\mathrm{B}=\mathrm{p}<0.05$ compare periods.

C-control; VS-venom and antivenom; VSM-venom, antivenom and aqueous extract of M. glomerata.

Units are as follows. Urea and creatinine: $\mathrm{mg} / \mathrm{dL}$. Creatinine kinase: UI/L.

in bovine two to six hours after venom inoculation (Belluomini et al. 1982, Lago et al. 2000), and in dogs two, four and six hours after venom inoculation (Collicchio et al. 2002, Nogueira \& Sakate 2006, Nogueira et al. 2007). Our study did not show a significant difference between groups VS and VSM, thus differing from the results obtained by Maiorano et al. (2005), in which the venom's neurotoxic action was completely inhibited by extracts from fresh or dried roots and stems of $M$. glomerata. This difference was probably due to the use of a different part of the plant to treat the animals.

Blood incoaguability happened in a few animals but was neither statistically or clinically significant, probably due to the low sensitivity that this species has to crotalic venom. However, Maiorano et al. (2005) reported results with $M$. glomerata that showed that its extracts act as powerful inhibitors of clotting activity, probably due to interactions with thrombin-like enzymes.

The diminution in red blood cells, globular volume and hemoglobin after crotalic experimental envenomation is consistent with the hematological findings from Nogueira et al. (2007) and Nogueira \& Sakate (2006), who observed the same results in dogs.

Leukocytosis with neutrophilia that was observed in groups VS and VSM at M1 and
M2 in this study, together with lymphopenia at M2 and M3 in both groups, are consistent with other authors, and this may be due to inflammatory processes and stress caused by general pain (Santoro et al. 2008, Ferreira Junior \& Barraviera 2004, Nogueira et al. 2007).

The average total plasma protein, fibrinogen, urea and creatinine values were within reference values for the species and no differences among treatments were observed.

Crotalic venom has a myotoxic action (Nogueira et al. 2007, Azevedo-Marques et al. 1985, Bucaretchi et al. 2002, Ferreira Junior \& Barraviera 2004), and creatine kinase is important in identifying muscle lesions (Kaneko et al 1997). The myotoxic action promotes widespread myalgy and myoglobinuria (AzevedoMarques et al. 1985, Magalhães et al. 1986, Motta et al. 2007).

This study showed an increase in CK values for groups VS and VSM at M1 and M2, consistent with the authors that mention that crotalic venom has effects on muscle fibers (Azevedo-Marques et al. 1985, Lago et al. 2000).

There was no statistical difference $(\mathrm{p}>0.05)$ among treatments, but the values of CK were higher in animals of group VS. The aqueous extract of $M$. glomerata might have lowered CK values for animals of group VSM by 
inhibiting the action of phospholipase A2, as described by Maiorano et al. (2005). A deeper investigation with histological analysis of the fabric of the member inoculated is necessary.

\section{RESUMEN}

El envenamiento crotálico representa el número más alto de muertes cuando es comparado con envenenamientos por mordeduras de otras serpientes de interés médico. El veneno crotálico tiene importantes características de acción neurotóxica, miotoxicidad, nefrotoxicidad, coagulación y acción hemolítica. Este trabajo evaluó los aspectos clínicos y de laboratorio del envenenamiento experimental con el veneno de la serpiente Crotalus durissus terrificus en las ratas Wistar tratadas con suero antiofídico y extracto acuoso de $M$. glomerata. Los animales fueron separados en tres diferentes grupos: grupo control (C); grupo veneno+suero (VS), grupo veneno+suero+extracto acuoso de M. glomerata (VSM). El veneno crotálico causó alteraciones clínicas y diferencias en los análisis sanguíneos practicados a los ratones Wistar evaluados. Las alteraciones clínicas más importantes fueron una disminución de la temperatura, edema en el miembro inoculado de veneno, la sedación y una disminución de la locomoción en los grupos VS y VSM comparado con el grupo C. Una rápida recuperación de la sedación estadísticamente significativa fue observada en los animales del grupo VSM al compararse con los del grupo VS. Los análisis sanguíneos mostraron un aumento en el número de leucocitos, neutrofilos y creatina quinasa en los grupos VS y VSM comparados con el grupo C. Los ratones Wistar mostraron una alta resistencia al veneno del crótalo. Estudios adicionales con variación en las dosis, tiempo de tratamiento, y métodos de administración, así como la realización de estudios histopatológicos e inmunológicos son importantes para comprender la acción de $M$. glomerata en accidentes crotálicos.

Palabras clave: Crotalus durissus terrificus, Mikania glomerata, suero antiofídico, rata, veneno

\section{REFERENCES}

Amaral, C.F.S., N.A. Rezende \& A.O. Silva. 1986. Insuficiência renal aguda secundária a acidentes ofídicos botrópico e crotálico: Análise de 63 casos. Rev. Inst. Méd. Trop. 28: 220-227.

Amaral, C.F.S., N.A. Rezende \& T.M.G. Pedrosa. 1988. Afibrinogenemia secundária e acidente ofídicos crotálico (Crotalus durissus terrificus). Rev. Inst. Med. Trop. 30: 288-292.

Amaral, C.F.S., R.A. Magalhães \& N.A. Rezende. 1991. Comprometimento respiratório secundário e acidente ofídico crotálico. Rev. Inst. Méd. Trop. 33: 251-255.
Araújo, P. \& H.E. Belluomini. 1962. Toxicidade dos venenos ofídicos: sensibilidade específica de animais domésticos e de laboratório. Mem. Inst. Butantan. 30: $143-56$.

Azevedo-Marques, M.M., P. Cupo \& T.M. Coimbra. 1985. Myonecrosis, myoglobinuria and acute renal failure induced by South American rattlesnake (Crotalus durissus terrificus) envenomation in Brazil. Toxicon. 23: 631-636.

Barraviera, B. 1994. Acidentes por serpentes dos gêneros Crotalus e Micrurus, p. 281-95. In B. Barraviera (ed). Venenos animais: uma visão integrada. Editora de Publicações Biomédicas. Rio de Janeiro, Brazil.

Belluomini, H.E., P. Araújo, G. Rosenfeld, F.F. Leinz \& E.H. Birgel. 1982. Symptomatologie der experimentellen Crotalustoxin-Vergiftung bei Rindern, die einer spezifischen Serumtherapie unterworfen wurden. Dtsch. Tierärztl. Wschr. 89: 444-448.

Berkenhout, J. 1769. Outlines of the natural history of Great Britain and Ireland. Containing a systematic arrangement and concise description of all the animals, vegetables, and fossiles which have hitherto been discovered in these kingdoms. Vol. I. Comprehending the animal kingdom. London, United Kingdom.

Bucaretchi, F., S.R.F. Herrera \& S. Hyslop. 2002. Snakebites by Crotalus durissus ssp. in Campinas. Rev. Inst. Med. Trop. 44: 133-138.

Castro, I. 2006. Estudo da toxicidade das peçonhas crotálicas e botrópicas, no acidente ofídico, com ênfase a toxicidade renal. O Mundo Da Saúde 30: 644-653.

Collicchio, R.C., M. Sakate \& M.R.S. Balarin. 2002. Relato de caso: Alterações clínicas e laboratoriais conseqüentes à picada de cascavel (Crotalus durissus terrificus) em uma cadela gestante. Clínica Veterinária. São Paulo. 40: 45-48.

Curi, P.R. 1997. Metodologia e Análise de Pesquisa em Ciências Biológicas. Topomic, Sao Paulo, Brazil.

Ferreira, L.A.F., O.B. Henriques, A.A.S. Andreoni, G.R.F.Vital, M.M.C. Campos, G.G. Habermehl \& V.L.G. de Moraes. 1992. Antivenom and biological effects of ar-turmerone isolated from Curcuma longa (Zingiberaceae). Toxicon. 30: 1211-18.

Ferreira Junior, RS. \& B. Barraviera. 2004. Management of venomous snakebites in dogs and cats in Brazil. J. Venom. Anim. Toxins incl. Trop. Dis.10: 112-132.

Hudelson, S. \& P. Hudelson. 1995. Pathopysiology of snake envenomization and evaluation of treatmentsPart II. Comp. Cont. Educ. Pract. Vet. 17: 1035-40. 
Jain, N.C. 1993. Essentials of Veterinary Hematology. Lea \& Febiger. Philadelphia, USA.

Jorge, M.T. \& L.A. Ribeiro. 1992. Epidemiologia e quadro clínico do acidente por cascavel sul-americana (C. durissus). Rev. Inst. Méd. Trop. São Paulo. 34: 347-354.

Kaneko, J.J., J.W. Harvey \& M.L. Bruss. 1997. Clinical biochemistry of domestic animals. Academia. San Diego, California, USA.

Kelen, E.M.A., G. Rosenfeld \& F. Nudel. 1962. Hemolytic activity of animal venoms. II. Variation in relation to erythrocyte species. Mem. Inst. Butantan. 30: 133-142.

Kini, R.M. \& H.J Evans. 1989. A model to explain the pharmacological effects of snake venom phospholipases A2. Toxicon. 27: 613-35.

Lago, L.A., P.M. Ferreira \& E.J. Facury Filho. 2000. Quadro clínico do envenenamento crotálico experimental em bovinos (Crotalus durissus terrificus-crotamina positivo). Braz. J. Vet. Res. Anim. Sci. 37: 312-15.

Leite, M.G.R., C.L. Souza, M.A.M. Silva, L.K.A. Moreira, F.J.A. Matos \& G.S.B. Viana. 1993. Estudo farmacológico comparativo de Mikania glomerata Sprengel (guaco), Justicia pectoralis Jacq (anador) e Torresea cearensis (cumaru). Rev. Bras. Farm. 74: 12-15.

Magalhães, R.A., M.M.F. Ribeiro \& N.A.R. Rezende 1986. Rabdomiólise secundária a acidente crotálico (Crotalus durissus terrificus). Rev. Inst. Med. Trop. 28: 228-233.

Maiorano, V.A., S. Marcussi, M.A.F. Daher, C.Z. Oliveira, L.B. Couto, O.A. Gomes, S.C. França, A.M. Soares \& P.S. Pereira. 2005. Antiophidian properties of the aqueous extract of Mikania glomerata. J Ethnopharmacol.102: 364-370.

Melo, P.A., M.C. Nascimento, W.B. Mors, \& G. SuarezKurtz. 1994. Inhibition of the myotoxic and hemorrhagic activities of crotalid venoms by Eclipta prostata (Asteraceae) extracts and constituents. Toxicon. 32: 595-603.

Ministério da Saúde. 2001. Manual de diagnóstico e tratamento de acidentes por animais peçonhentos. Fundação Nacional de Saúde, Brasília, Brasil.

Ministério da Saúde. 2005. Guia de Vigilância Epidemiológica. Ministério da Saúde, Brasília, Brasil.
Motta, Y.P., M. Sakate, R.M.B. Nogueira, R.S. Floriano, O.C. Sanches, F. Sangiorgio, R. Fukui \& H. David. 2007. Avaliação histopatólogicas do rim e da musculatura em ratos wistar intoxcados experimentalmente com venenos botrópico e crotálico. In XV Congresso Brasileiro de Toxicologia, São Paulo: Sociedade Brasileira de Toxicologia 2007, Búzios. Revista Brasileira de Toxicologia. 20: 87-87.

Murtaugh, R.J. \& P.M. Kaplan. 1992. Veterinary emergency and critical care medicine. Mosby year book. Philadelphia, USA.

Nogueira, R.M.B. \& M. Sakate. 2006. Clinical and hematological alterations in dogs during experimental envenomation with Crotalus durissus terrificus venom and treated with antiophidic serum. J. Venom. Anim. Toxins incl. Trop. Dis. 12: 285-96.

Nogueira, R.M.B., M. Sakate, F. Sangiorgio, C.B. Laposy \& M. Melero. 2007. Experimental envenomation with Crotalus durissus terrificus venom in dogs treated with antiophidic serum-Part I: clinical evaluation, hematology and myelogram. J. Venom. Anim. Toxins 13: $800-10$

Pereira, N.A., B.M.R. Pereira, M.C. Nascimento, J.P. Parente \& W.B. Mors. 1994. Pharmacological screening of plants recommended by folk medicine as antisnake venom. IV. Proction against jararaca venom by isolated constituints. Planta Med. 60: 99- 100.

Pinho, F.M.O. \& I.D. Pereira. 2001. Ofidismo. Rev. Ass. Med. Brasil. 47: 24-29.

Raiser, A.G. 2002. Choque, p. 503-521. In S.F. Andrade (ed.). Manual de Terapêutica Veterinária. Roca, São Paulo, Brazil.

Rosenfeld, G., E.M.A. Kelen \& F. Nudel. 1962. Hemolytic activity of animal venoms. I. Classification in different types and activities. Mem. Inst. Butantan. 30: 103-116.

Santoro, M.L., I.S. Sano-Martins, H.W. Fan, J.L.C. Cardoso, R.D.G. Theakston, A. David \& D.A. Warrell. 2008. Haematological evaluation of patients bitten by the jararaca, Bothrops jararaca, in Brazil. Toxicon 51: $1440-1448$.

Silva, R.A. 1929. Pharmacopoeia dos Estados Unidos do Brasil. Nacional, São Paulo, Brazil.

Soares, AM., A.H. Januario, M.V. Lourenco, A.M.S. Pereira \& P.S. Pereira. 2004. Neutralizing effects of Brazilian plants against snake venoms. Drugs Future 29: 1105-1117. 
Soares, A.M., F.K. Ticli, S. Marcussi, M.V. Lourenco, A.H. Januario, S.V. Sampaio, J.R. Giglio, B. Lomonte \& P.S. Pereira. 2005. Medicinal Plants with inhibitory properties against snake venoms. Curr $\mathrm{Med}$ Chem. 12: 2625-41.

Vieira, C.A., L.O. Vieira, J.J.R. Bueno, M.R.M. Debiasi, A.C. Mancim \& J.R. Giglio. 2006. Ação de vários agentes sobre o efeito paralisante dos membros posteriores induzido pela crotamina em camundongos. Biosc. J. 22: 125-32.
Vital-Brazil, O. 1972. Neurotoxins from the South American rattlesnake. Venon. J. Formos. Med. Assoc. 71: 394-400.

\section{INTERNET REFERENCES}

Ministério da Saúde. 2006. Sistema de Informação de Agravos de Notificações. Ministério da Saúde, Brasília, Brasil. (Downloaded: February 16, 2007, http:// portal.saude.gov.br/portal/saude/visualizar_texto. cfm?idtxt=21429). 
